GSA Data Repository 2016088

\title{
Partial collapse of the marine carbon pump after the Cretaceous-
}

\section{Paleogene boundary}

Heather S. Birch et al.

\section{SUPPLEMENTARY INFORMATION}

\section{Adjustment factors}

3 Improved understanding of modern and early Paleocene planktonic foraminifera ecologies

4 and their associated carbon disequilibrium effects (Birch et al., 2013) allows refinement of K/Pg

$5 \quad \delta^{13} \mathrm{C}$ gradients through the application of $\delta^{13} \mathrm{C}$ adjustment factors. Two principal $\delta^{13} \mathrm{C}$ vital

6 effects are considered. The procedure of selecting realistic adjustment factors is discussed.

7 1. The metabolic effect. This effect results from the decreasing influence of metabolic

8 (isotopically light) $\mathrm{CO}_{2}$ on test calcite $\delta^{13} \mathrm{C}$ through ontogeny (Berger et al., 1978). Metabolic

9 fractionation, which influences small $(<150 \mu \mathrm{m})$ tests, has been suggested to depress test $\delta^{13} \mathrm{C}$ by

10 up to $2 \%$ relative to ambient DIC $\delta^{13} \mathrm{C}$ values.

11 Most planktic foraminifera species occurring in the immediate aftermath of the $\mathrm{K} / \mathrm{Pg}$

12 extinction, both survivors and newly evolved taxa, are small $(<150 \mu \mathrm{m})$ and record $\delta^{13} \mathrm{C}$ that is

13 consistently lower than inferred ambient DIC by $\sim 0.3$ to $0.5 \%$ (D’Hondt and Zachos, 1993;

14 Birch et al., 2012). For this reason our Site 1262 G. cretacea and H. holmdelensis records were

15 adjusted by adding $0.4 \%$ to each $\delta^{13} \mathrm{C}$ value (adjusted $\delta^{13} \mathrm{C}$ Option-1 (Table DR1, Figure DR2).

16 This value of $0.4 \%$ was selected initially because the isotopic depletion was previously shown to 
17 be greatest in the smallest size fractions $(80-125 \mu \mathrm{m})$ and specimens of these taxa from the early

18 Danian are particularly small $(65-125 \mu \mathrm{m})$.

19 2. The photosymbiosis effect. In some planktonic foraminifera species of larger test sizes

$20(>150 \mu \mathrm{m})$ have a relationship with symbiotic algae, which causes $\delta^{13} \mathrm{C}$ values to be enriched by

21 up to 1.5\% (Spero and DeNiro, 1987; D’Hondt and Zachos, 1994; Norris 1996). The amount of

$22 \delta^{13} \mathrm{C}$ enrichment is dependent on the test size and the species in question.

23 Analysis of $\delta^{13} \mathrm{C}-$ test size relationships in early Paleocene planktonic foraminifera

24 reveals that this signal first appears in Praemurica .ca. 63.5Ma (Birch et al., 2012). At first the

$25 \delta^{13} \mathrm{C}$ - test size correlations and, thus inferred dependence on symbiosis, were relatively weak,

26 but strengthened in later species of Morozovella, including M. angulata, which was analyzed in

27 the upper part of the section, implying increased dependence on symbiosis over time. For this

28 reason the adjustment factor for symbiosis has been split into two categories; weak symbiosis

29 and full symbiosis. Weak symbiosis is associated with ${ }^{13} \mathrm{C}$ enrichment between 0.1 and $0.3 \%$

30 (relative to ambient DIC $\delta^{13} \mathrm{C}$ ) over the full test size spectrum for a single taxon (Birch et al.,

31 2012). The specimens picked here were at the larger end of the spectrum $(>212 \mu \mathrm{m})$, thus they

32 were 'adjusted to' ambient DIC values by subtracting $0.3 \%$ from measured test $\delta^{13} \mathrm{C}$. Full

33 symbiosis is associated with ${ }^{13} \mathrm{C}$ enrichment in the range of 0.5 to $1.5 \%$. The specimens of $M$.

34 angulata analyzed here were of medium to large size $(180$ to $>250 \mu \mathrm{m})$ thus, an adjustment value

35 of $1.0 \%$ was subtracted from measured test $\delta^{13} \mathrm{C}$. These adjustment factors are incorporated in

36 'adjusted $\delta^{13} \mathrm{C}$ Option-1' (Table DR1, Figure DR2). Praemurica taurica and Subbotina sp. show

37 no marked size related disequilibrium effects and therefore are not adjusted.

When applied to the down-hole $\delta^{13} \mathrm{C}$ record (Figure DR2) the adjustment factors of

39 Option-1 moved some species to unrealistic positions relative to others and bulk values. 
40 Significantly, $H$. holmdelensis $\delta^{13} \mathrm{C}$ values increased above those of co-occurring asymbiotic

41 surface mixed dweller Gl. falsostuarti. The 'weak photosymbiosis-adjusted' Praemurica and $M$.

42 praeangulata $\delta^{13} \mathrm{C}$ values plot just above the thermocline species and in line with the bulk

43 carbonate $\delta^{13} \mathrm{C}$ values, which makes sense for a species living in the photic zone. However,

44 application of the Option-1 'full photosymbiosis' adjustment to $M$. angulata and R. fructicosa

45 forces these taxa to $\delta^{13} \mathrm{C}$ values lower than the thermocline (i.e. base of the mixed layer/photic

46 zone) species Subbotina spp. Consequently we came up with a second combination of

47 adjustment factors ('adjusted $\delta^{13} \mathrm{C}$ Option-2'; Table DR1, Figure DR2; Figure 2 Panel E) that

48 better meet the expected water column targets as predicted by paired $\delta^{18} \mathrm{O}(\mathrm{depth})$ ecology and

49 other reference species. Our preferred solution (Table DR1; Figure 2 Panel E) 'Option 2': added

$50 \quad 0.4 \%$ o to $\delta^{13} \mathrm{C}$ of $G$. cretacea to account for the metabolic vital effect, but left $H$. holmdelensis as

51 it was; Pr. inconstans and M. praeangulata $\delta^{13} \mathrm{C}$ were left with subtracting $0.3 \%$, in which

52 evidence for 'weak' photosymbiotic fractionation was detected. $0.3 \%$ was subtracted from early

53 smaller $(<250 \mu \mathrm{m})$ M. angulata $\delta^{13} \mathrm{C}$ and $0.6 \%$ to larger $(>250 \mu \mathrm{m})$ specimens found after

$5461.98 \mathrm{Ma}$, as this species becomes increasingly enriched in ${ }^{13} \mathrm{C}$. The values used in this more

55 refined option 2 were achieved by looking at the species specific $\delta^{13} \mathrm{C}$ gradient change with size

56 from Birch et al., (2012). R. fructicosa, with test sizes $>300 \mu \mathrm{m}$, had the larger value of $0.6 \%$ o

57 subtracted. This exercise emphasizes the need for repeatedly evaluating planktonic foraminiferal

58 paleoecologies and the magnitude of likely disequilibrium fractionation effects because they vary

59 depending on the evolutionary phase as well as between location and environments.

60

61 REFERENCES CITED

62 Berger, W.H., Killingley, J.S., Vincent, E., 1978, Stable isotopes in Deep-Sea carbonates -

63 box core Erdc-92, West Equatorial Pacific. Oceanologica Acta v. 1, 203-216. 
Birch, H.B., Coxall, H.K. \& Pearson, P.N., 2012, Evolutionary ecology of Early Paleocene planktonic foraminifera: Size, depth habitat and symbiosis. Paleobiology v. 38, 374-390.

Birch, H., Coxall, H., Pearson, P., Kroon, D., and O'Regan, M., 2013, Planktonic foraminifera stable isotopes and water column structure: Disentangling ecological signals: Marine Micropaleontology, v. 101, p. 127-145, doi:10.1016/j.marmicro.2013.02.002.

D'Hondt, S., and Zachos, J. C., 1993, On stable isotopic variation and earliest Paleocene

Norris, R.D., 1996, Symbiosis as an evolutionary innovation in the radiation of Paleocene

D'Hondt, S., Zachos, J. C., and Schultz, G., 1994, Stable isotopic signals and photosymbiosis in late Paleocene planktic foraminifera: Paleobiology, v. 20, no. 3, p. 391-406. planktic foraminfera. Paleobiology, v. 22, 461-480. and $\delta^{13} \mathrm{C}$ values of planktonic foraminiferal shell calcite. Symbiosis v. 4, 213-228.

\section{Table DR1}

\begin{tabular}{|c|c|c|c|c|c|}
\hline Species & Test Size & $\begin{array}{c}\text { Type of } \\
\text { disequilibrium }\end{array}$ & $\delta^{13} \mathrm{C}$ Offset Range & $\begin{array}{c}\text { Option } 1 \delta^{13} \mathrm{C} \\
\text { Adjustment }\end{array}$ & $\begin{array}{c}\text { Option } 2 \delta^{13} \mathrm{C} \\
\text { Adjustment }\end{array}$ \\
\hline G cretacea & $<150 \mu \mathrm{m}$ & Metabolic & $-0.3-0.5 \%$ & $+0.4 \%$ & $+0.4 \%$ \\
\hline H. holdelensis & $<150 \mu \mathrm{m}$ & Metabolic & $-0.3-0.5 \%$ & $+0.4 \%$ & not adjusted \\
\hline M. praeangulata & $>150 \mu \mathrm{m}$ & $\begin{array}{c}\text { Weak } \\
\text { symbiosis }\end{array}$ & $+0.1-0.3 \%$ & $-0.3 \%$ & $-0.3 \%$ \\
\hline Pr. inconstans & $>150 \mu \mathrm{m}$ & $\begin{array}{c}\text { Weak } \\
\text { symbiosis }\end{array}$ & $+0.1-0.3 \%$ & $-0.3 \%$ & $-0.3 \%$ \\
\hline M. angulata & $<250 \mu \mathrm{m}$ & $\begin{array}{c}\text { Weak } \\
\text { symbiosis }\end{array}$ & $+0.1-0.3 \%$ & $\begin{array}{l}\text { Weak \& full } \\
\text { not separated }\end{array}$ & $-0.3 \%$ \\
\hline M. angulata & $>250 \mu \mathrm{m}$ & Full symbiosis & $+0.5-1.5 \%$ & $-1.0 \%$ & $-0.6 \%$ \\
\hline R. fructicosa & $>150 \mu \mathrm{m}$ & Full symbiosis & $+0.5-1.5 \%$ & $-1.0 \%$ & $-0.6 \%$ \\
\hline
\end{tabular}

87 Table DR1- Calculated $\delta^{13} \mathrm{C}$ adjustment factors (option $1 \& 2$ ) applied to species with known 
Table DR2 - Benthic and planktonic foraminifera stable isotopes $\left(\delta^{13} \mathrm{C}\right.$ and $\left.\delta^{18} \mathrm{O}\right)$ results from ODP Site 1262 against astronomically tuned ages (Dinarès-Turrell et al., 2014) and meters composite depth (MCD).

93

\section{$94 \quad$ Figure caption}

95

96 Figure DR1 - Location of ODP Site 1262 at Walvis Ridge, South East Atlantic.

Figure DR2 - Benthic and planktonic foraminifera stable isotopes $\left(\delta^{13} \mathrm{C}\right), \mathbf{A}$ - before adjustment,

100 B - with adjustment option 1 and $\mathbf{C}$ - with adjustment option 2 (Table DR1), against age (Ma)

101 based on the time scale of Dinarès-Turrell et al., (2014) from site 1262. Genera abbreviations as

102 follows $\mathrm{M}=$ Morozovella, $\mathrm{Pr}=$ Praemurica, $\mathrm{S}=$ Subbotina, $\mathrm{N}=$ Nuttallides, $\mathrm{R}=$

103 Racemiguembelina, $\mathrm{Gl}=$ Globotruncana, $\mathrm{G}=$ Guembelitria, and $\mathrm{H}=$ Hedbergella . 
Supplementary information

Figure DR1 - Location of ODP Site 1262 at Walvis Ridge, South East Atlantic

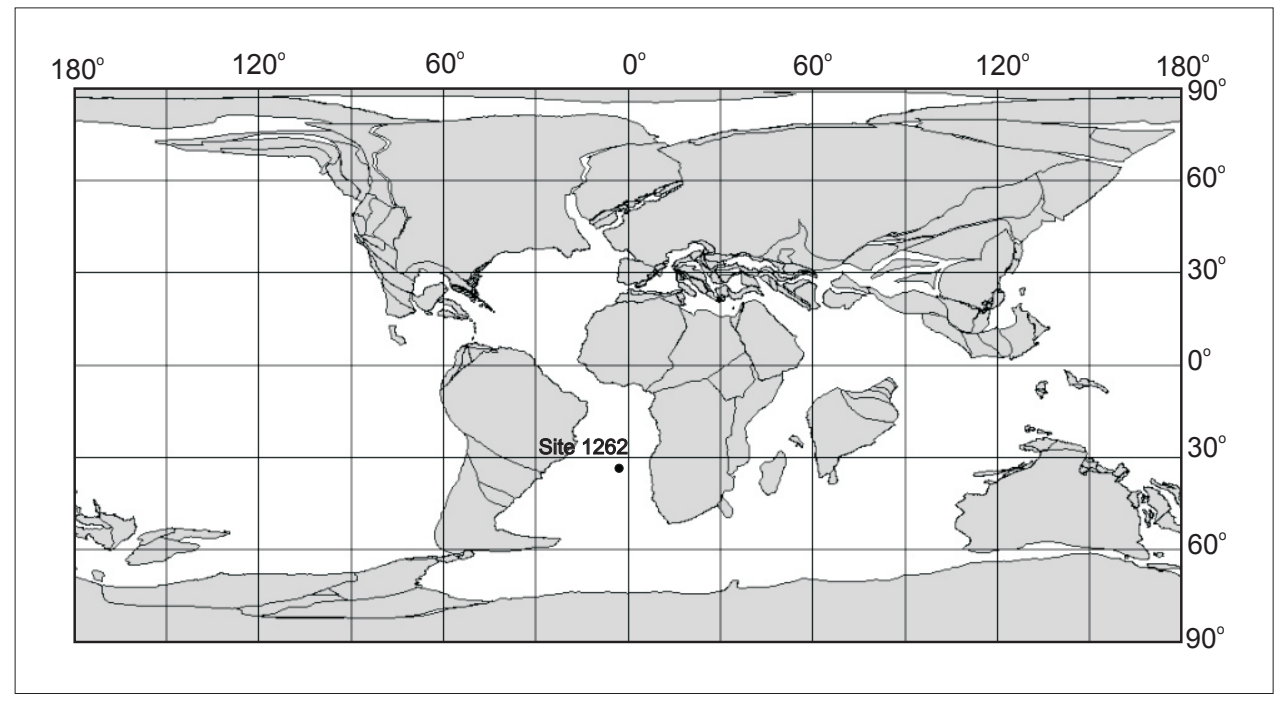


Figure DR2 - Benthic and planktonic foraminifera stable isotopes $\left(\Delta^{13} \mathrm{C}\right) \mathrm{A}$ - before adjustment, $B$ - with adjustment option 1 and $C$ - with adjustment option 2 (Table DR1), against age (Ma) based on the time scale of Dinarès-Turrell et al., (2014) from site 1262. Genera abbreviations as follows $\mathrm{M}=$ Morozovella, $\mathrm{Pr}=$ Praemurica, $\mathrm{S}=$ Subbotina, $\mathrm{N}=$ Nuttallides, $\mathrm{R}=$ Racemiguembelina, $\mathrm{Gl}=$ Globotruncana, $\mathrm{G}=$ Guembelitria, and $\mathrm{H}=$ Hedbergella.

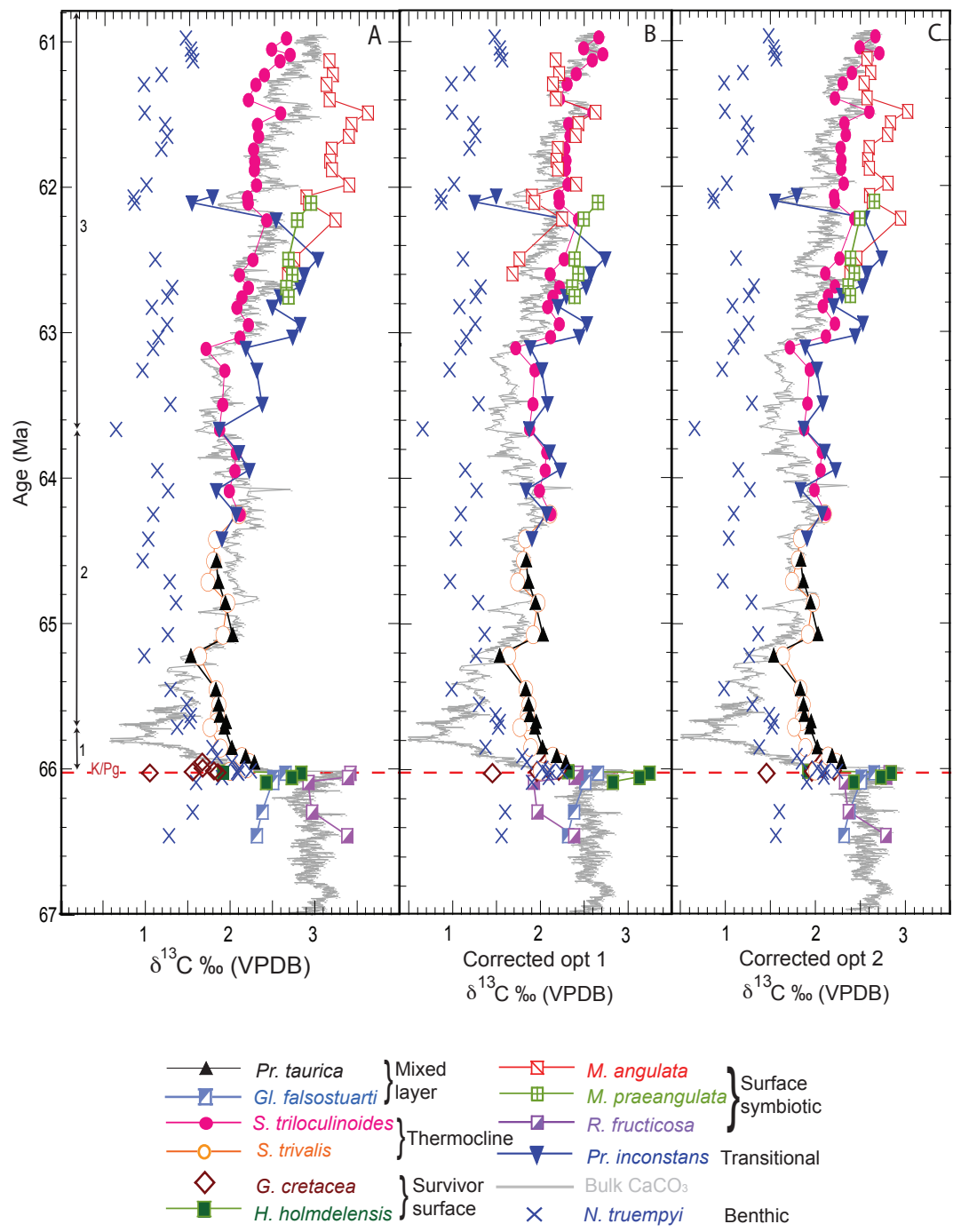

